\title{
Contrasted evolution of glacial lakes along the Hindu Kush Himalaya mountain range between 1990 and 2009.
}

Julie Gardelle $^{\mathrm{a}^{*}}$, Yves Arnaud ${ }^{\mathrm{a}, \mathrm{b}}$, Etienne Berthier ${ }^{\mathrm{c}}$

*Corresponding author: julie.gardelle@1gge.obs.ujf-grenoble.fr. Tel.: +33 476824206.

${ }^{a}$ Laboratoire de Glaciologie et Géophysique de l'Environnement, CNRS, UJF-Grenoble, 54 rue Molière, BP 96, 38402 Saint Martin d'Hères, France.

${ }^{b}$ Laboratoire d'études des Transferts en Hydrologie et Environnement, IRD, 1023 rue de la Piscine, BP 53, 38401 Grenoble Cedex 09, France.

${ }^{c}$ CNRS; Université de Toulouse ; LEGOS; 14 Av. Ed. Belin, 31400 Toulouse, France

Citation: Julie Gardelle, Yves Arnaud, Etienne Berthier, Contrasted evolution of glacial lakes along the Hindu Kush Himalaya mountain range between 1990 and 2009, Global and Planetary Change, Volume 75, Issues 1-2, January 2011, Pages 47-55, DOI: 10.1016/j.gloplacha.2010.10.003

\begin{abstract}
In this study, we present a first regional assessment of glacial lake distribution and evolution in the Hindu Kush Himalaya (HKH). Seven sites have been selected between Bhutan and Afghanistan, to capture the climatic variability along the $2000-\mathrm{km}$ long mountain range. For each site, glacial lakes have been mapped with LANDSAT satellite imagery acquired in 1990, 2000 and 2009, using an automatic classification. In the East (India, Nepal and Bhutan), glacial lakes are bigger and more numerous than in the West (Pakistan, Afghanistan), and have grown continuously between 1990 and 2009 by $20 \%$ to $65 \%$. On the other hand, during the same period, the glacial lake coverage has shrunk in the Hindu Kush (-50\%) and the Karakorum ($30 \%$ ). This east/west pattern of lake changes seems in agreement with sparse glaciological measurements that suggest less (or even no) ice loss in the western part of the HKH.
\end{abstract}

Keywords: Glacial lakes, Himalaya, Remote sensing

\section{Introduction}

Little is currently known about the distribution and evolution of glacial lakes in the vast Hindu Kush Himalaya $(\mathrm{HKH})$ mountain range although those lakes are potentially an indirect indicator of glacier change and, in certain cases, threaten the life of the inhabitants of the mountain valleys (Richardson and Reynolds, 2000).

Two types of glacial lakes can be distinguished: (i) pro-glacial lakes, often growing downstream of steep glaciers, where water is collected behind former moraines (Richardson and Reynolds, 2000; Komori, 2008); (ii) supra-glacial lakes, which develop on the surface of the glacier itself, growing by coalescence of small ponds. They tend to develop on long, flat, debris-covered valley glaciers which respond to a negative mass balance by thinning (downwasting) rather than by a terminus retreat (Reynolds, 2000; Richardson and Reynolds, 2000; Quincey et al., 2007; Komori, 2008).

Recent expansion of glacial lakes in the Himalaya has mainly been studied in north Bhutan (Fujita et al., 2008; Komori, 2008) and in the Everest region (Yamada and Sharma, 1993; Sakai et al., 2000; Benn et al., 2001; Wessels et al., 2002; Bolch et al., 2008a). However, the distribution and the temporal evolution of glacial lakes over the entire HKH range have never been addressed yet. As suggested by Kargel et al. (2005), glacier and glacial lake evolution are likely to be very different between the eastern part of the mountain range where the large majority of glaciers are retreating and the western part where glacier changes are slower. The purpose of this paper is thus to give an overview of the distribution and recent evolution of 
glacial lakes along the HKH range, from Bhutan to Afghanistan. To achieve this goal, a set of optical satellite images has been used, with a time coverage spreading from 1989 to 2009.

\section{Study area and data}

\subsection{Study area}

The HKH region, ranging from Afghanistan to Bhutan, is covered by about $60,000 \mathrm{~km}^{2}$ of glaciers (Dyurgerov and Meier, 2005). Precipitation regimes are driven by the Indian monsoon in summer (precipitation occurring from June to September) and by the mid-latitude westerlies in winter (precipitation occurring from January to April) (Böhner, 2006). The precipitation pattern is characterized by two gradients (Bookhagen and Burbank, 2006): (i) a north-south gradient due to the orographic barrier, preventing air masses to go further north, (ii) an east-west gradient, due to the weakening westwards of the Indian monsoon coming from the Bay of Bengal, and implying a greater humidity in the eastern $\mathrm{HKH}$.

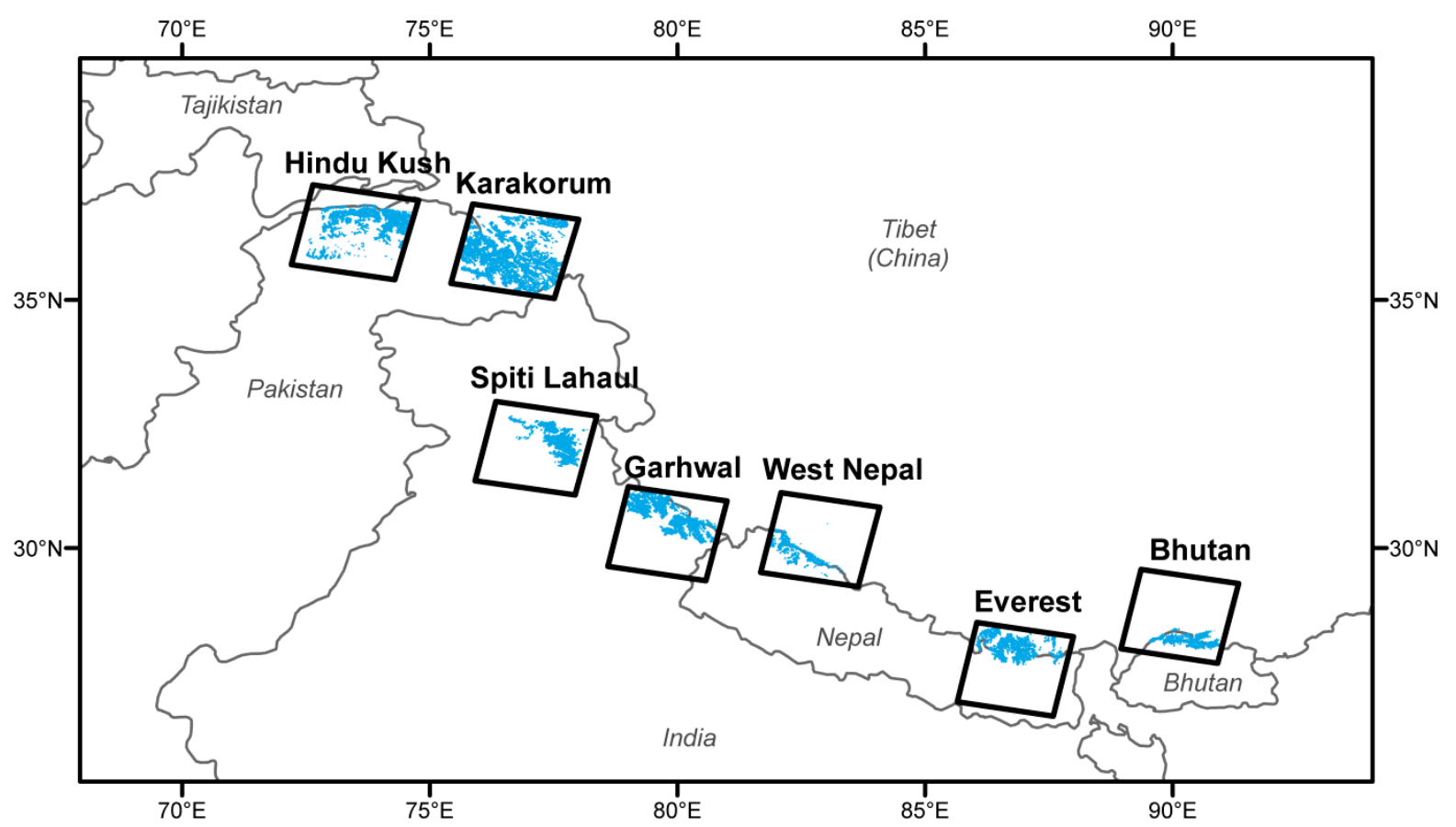

Figure 1: Location of the seven study sites along the HKH range (their names appear in bold on the map). For each site, the footprint of a LANDSAT image is shown. Ice covered areas are represented by blue filled polygons.

In order to study glacial lakes over the HKH region, seven study sites (comprising a high proportion of glaciarized area) have been selected along the mountain range, so as to be representative of the climatic gradients (Table 1). Their locations are presented in Figure 1. Their extent corresponds to the footprint of a LANDSAT image, i.e. $31110 \mathrm{~km}^{2}$. These seven study sites encompass approximatively $24100 \mathrm{~km}^{2}$ of glaciers, or $40 \%$ of the total ice-covered area in the HKH (Table 2). Bhutan, Everest and West Nepal sites are directly influenced by the Indian monsoon, summer being both ablation and accumulation seasons on glaciers (Fujita, 2008). Western sites, namely Hindu Kush and Karakorum, are much dryer, with precipitation occurring mainly during winter. Between these two extreme parts of the HKH region, the Spiti Lahaul and Garhwal sites represent a transition zone, influenced by both the summer monsoon and the winter westerlies (Figure 2). 


\begin{tabular}{lccc}
\hline \multicolumn{1}{c}{ Site name } & \multicolumn{2}{c}{ Mean annual temperature $\left({ }^{\circ} \mathbf{C}\right)$} & $\begin{array}{c}\text { Mean annual } \\
\text { precipitation }(\mathbf{m})\end{array}$ \\
\hline Bhutan & -0.2 & -3.7 & 1.03 \\
Everest & -0.2 & -5.5 & 1.04 \\
West Nepal & -1.2 & -6.9 & 0.91 \\
Garhwal & -1.7 & -4.5 & 0.87 \\
Spiti Lahaul & -2.4 & -2.5 & 0.86 \\
Karakorum & -3.7 & -3.3 & 0.30 \\
Hindu-Kush & -4.5 & -0.8 & 0.35 \\
\hline
\end{tabular}

Table 1: Climate characteristics of the seven study sites (temperatures at 600hPa and interpolated between two pressure levels at the mean lake altitude from NCEP/DOE-Reanalysis 2, precipitation from Global Precipitation Climatology Project).

\begin{tabular}{lcccccc}
\hline \multicolumn{1}{c}{ Site name } & $\begin{array}{c}\text { Glacier } \\
\text { area }\left(\mathbf{k m}^{\mathbf{2}}\right)\end{array}$ & $\begin{array}{c}\text { Glacier mean } \\
\text { altitude (m) }\end{array}$ & $\begin{array}{c}\text { Front mean } \\
\text { altitude (m) }\end{array}$ & $\begin{array}{c}\text { Lake mean } \\
\text { altitude (m) }\end{array}$ & $\begin{array}{c}\text { Number } \\
\text { of lakes }\end{array}$ & $\begin{array}{c}\text { Total lake } \\
\mathbf{a r e a}_{(\mathbf{k m}} \mathbf{( \mathbf { k } )}\end{array}$ \\
\hline Bhutan & 1510 & 5600 & 4836 & 4814 & 203 & 27.2 \\
Everest & 2919 & 5614 & 5084 & 5079 & 583 & 29.1 \\
West Nepal & 960 & 5431 & 5128 & 5117 & 116 & 16.6 \\
Garhwal & 3910 & 5337 & 4278 & 4683 & 233 & 2.2 \\
Spiti Lahaul & 2854 & 5091 & 4129 & 4209 & 35 & 1.9 \\
Karakorum & 8718 & 5153 & 3609 & 4129 & 422 & 3.7 \\
Hindu-Kush & 3229 & 4617 & 3206 & 3622 & 102 & 0.7 \\
\hline
\end{tabular}

Table 2: Glaciers and lakes characteristics of the seven study sites. A LANDSAT scene covers in total $\sim 31110 \mathrm{~km}^{2}$, but on each site, only the part of the scene covered with glaciers has been analyzed.

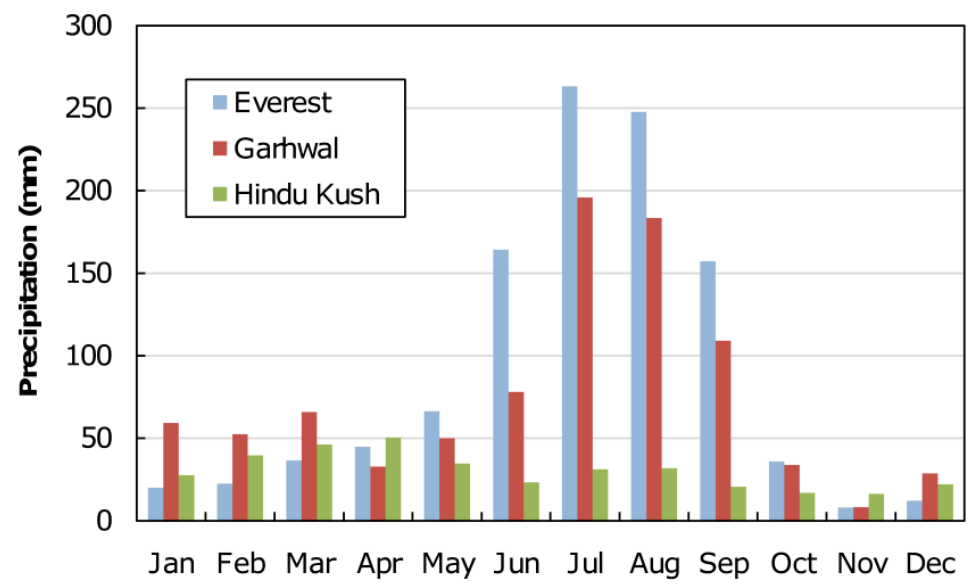

Figure 2: Monthly precipitations from Global Precipitation Climatology Project for three study sites: Everest, Garhwal and Hindu Kush.

\subsection{Data}

To avoid cloud cover during the monsoon and ensure minimal snow coverage, we selected satellite images acquired between September and November (for the eastern part) and between June and October (for the western part). Each of the seven study sites has been observed with two LANDSAT-TM and a LANDSATETM image with a spatial resolution of $30 \mathrm{~m}$ (images downloaded from http://glcf.umiacs.umd.edu and 
http://glovis.usgs.gov). The images were already radiometrically corrected and projected in the UTM coordinate system. Acquisition dates are listed in Table 3.

\begin{tabular}{lccc}
\hline \multicolumn{1}{c}{ Site name } & \multicolumn{3}{c}{ LANDSAT } \\
\hline \multirow{2}{*}{ Bhutan } & $14 / 11 / 1990$ & $04 / 11 / 2001$ & $17 / 10 / 2009$ \\
Everest & $17 / 11 / 1992$ & $30 / 10 / 2000$ & $31 / 10 / 2009$ \\
West Nepal & $21 / 10 / 1992$ & $03 / 10 / 2000$ & $18 / 09 / 2009$ \\
Garhwal & $15 / 11 / 1990$ & $15 / 10 / 1999$ & $12 / 06 / 2009$ \\
Spiti Lahaul & $09 / 10 / 1989$ & $15 / 10 / 2000$ & $01 / 11 / 2009$ \\
Karakorum & $29 / 06 / 1990$ & $12 / 10 / 2002$ & $21 / 09 / 2009$ \\
Hindu-Kush & $26 / 07 / 1989$ & $16 / 09 / 1999$ & $19 / 09 / 2009$ \\
\hline
\end{tabular}

Table 3: Dates (format is DD/MM/YYYY) of the images used in this study.

For each study site, a digital elevation model (DEM) of 2000 from the SRTM (Shuttle Radar Topography Mission) has also been downloaded at http://srtm.csi.cgiar.org/, with a spatial resolution of $90 \mathrm{~m}$.

Glacier inventories have been obtained from the GLIMS (Global Land Ice Measurements from Space, Raup et al., 2007) and ICIMOD (International Center for Integrated Mountain Development, ICIMOD, 2007) databases, which provide glacier outlines associated with various attributes, such as glacier length, area and orientation.

Finally, to analyze climate variability along the $\mathrm{HKH}$, monthly air temperatures at $600 \mathrm{hPa}$ and at the lake altitude were extracted from NCEP/DOE (National Centers for Environmental Prediction/Department of Energy) reanalysis- 2 data on a $2.5^{\circ} \times 2.5^{\circ}$ grid (Kanamitsu et al., 2002) since 1979 . Temperatures at $600 \mathrm{hPa}$ are used as an indicator of the overall trend in temperatures along the HKH range, whereas temperatures at mean glacial lake altitude are used to interpret glacial lake evolution. The latter are computed by interpolating temperature data between two pressure levels enclosing the mean glacial lake altitude. Precipitations have been analyzed through the Global Precipitation Climatology Project, providing monthly values on a $2.5^{\circ} \times 2.5^{\circ}$ grid since 1979 (GPCP, Huffman and Bolvin, 2009). Time series of monthly temperature and precipitation in the middle of each study site during each decade since 1979 were computed using a bilinear interpolation, based on the four surrounding grid points.

\section{Methodology}

Others authors previously addressed the question of mapping glacier lakes from multispectral satellite imagery. Wessels et al. (2002) performed a spectral analysis of terrain features in the Mount Everest region based on ASTER imagery, outlining the importance of water turbidity when monitoring glacial lakes. A similar spectral analysis has been carried out with one of our LANDSAT scene (Figure 3). The more turbid a glacial lake is, the higher its reflectance in the Visible and Near Infra-Red (VNIR) is, mainly because of the high suspended sediment load. As we are considering optical images, shadowing is problematic, especially in mountainous area when the solar zenith angle is high. It is important to notice that the spectral signature of these shadow areas (black line in Figure 3) is very similar to the one of glacial lakes with low turbidity.

Wessels et al. (2002) also discussed the automatic classification of glacial lakes. Using the four bands in the VNIR and MIR (Middle Infra-Red) of ASTER data, they computed two ratios to distinguish (i) water surfaces from non-water surfaces, with ratio $\mathrm{R}_{1}$ (Equation 1) (ii) solid (ice or snow) from liquid (free water) surface, among classified water surfaces, with ratio $\mathrm{R}_{2}$ (Equation 2).

$$
R_{1}=\frac{B_{G r e E n}}{B_{\text {NIR }}}
$$




$$
R_{2}=\frac{B_{N I R}}{B_{M I R}}
$$

where $B_{i}$ is the ASTER spectral band. However, this algorithm is not robust enough to be applied to images whose channels slightly differ from the ASTER sensor.

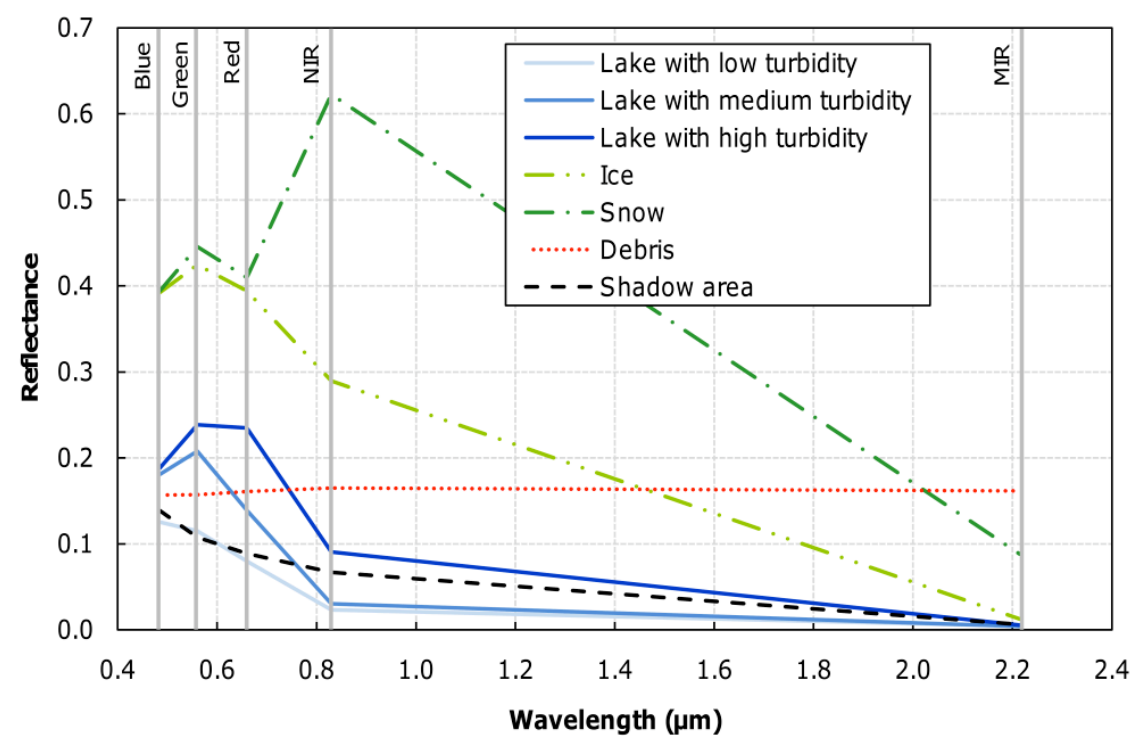

Figure 3 : Spectral signatures of several recurrent terrain features of the HKH, based on a LANDSAT-ETM image from November 2001 (Bhutan). Wavelength of LANDSAT-TM and ETM channels are indicated with gray bars.

Using LANDSAT images to study glacier hazards in the Swiss Alps, Huggel et al. (2002) applied the NDWI (Normalized Difference Water Index, Equation 3) to classify glacial lakes, taking advantage of the low water reflectance in the NIR band. However, they noticed that with this method, glacial lakes could be misclassified as shadow area.

$$
N D W I=\frac{B_{\text {NIR }}-B_{B l u e}}{B_{N I R}+B_{B l u e}}
$$

Given our satellite dataset (LANDSAT-TM and -ETM), the automatic classification has been carried out both with ratios $\mathrm{R}_{1}$ and $\mathrm{R}_{2}$, and with NDWI, using a decision tree (the complete algorithm is given in Figure 4). A threshold on the terrain slope was introduced, in order to discriminate self-shadow areas misclassified as glacial lakes. A slope map is computed with a $3 \times 3$ pixels window using the SRTM DEM and lakes are assumed to be areas where the slope is lower than $10 \%$ (to account for the DEM uncertainties and low resolution).

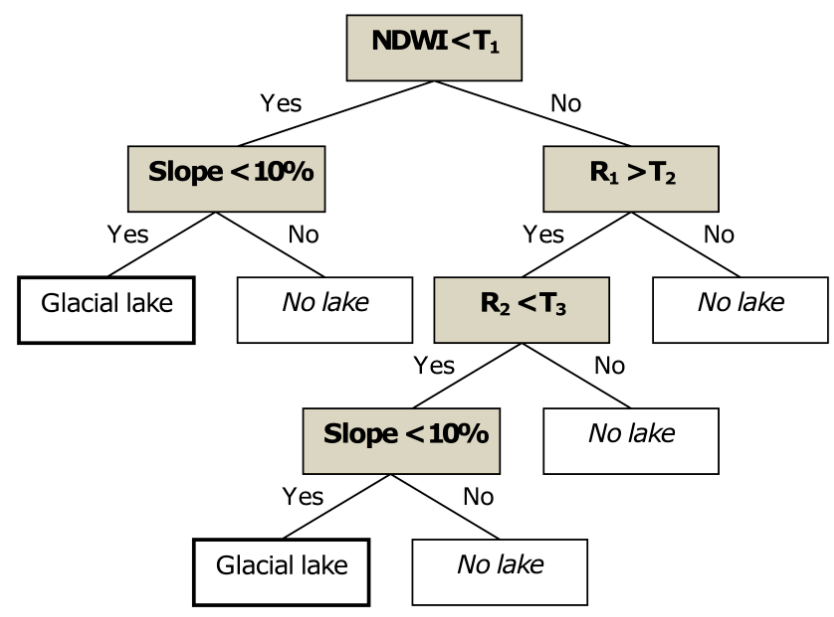

Figure 4: Algorithm to automatically classify glacial lakes on LANDSAT images, using a decision tree. $T_{i}$ represents a threshold, whose value is determined empirically on each scene by visual inspection. 
When lakes are frozen and covered by snow, they cannot be distinguished from snowy glaciers using automatic classification. Therefore, a visual inspection is necessary to browse and detect unclassified lakes. The result of the classification for a sub-scene of the West Nepal site is given in Figure 5.
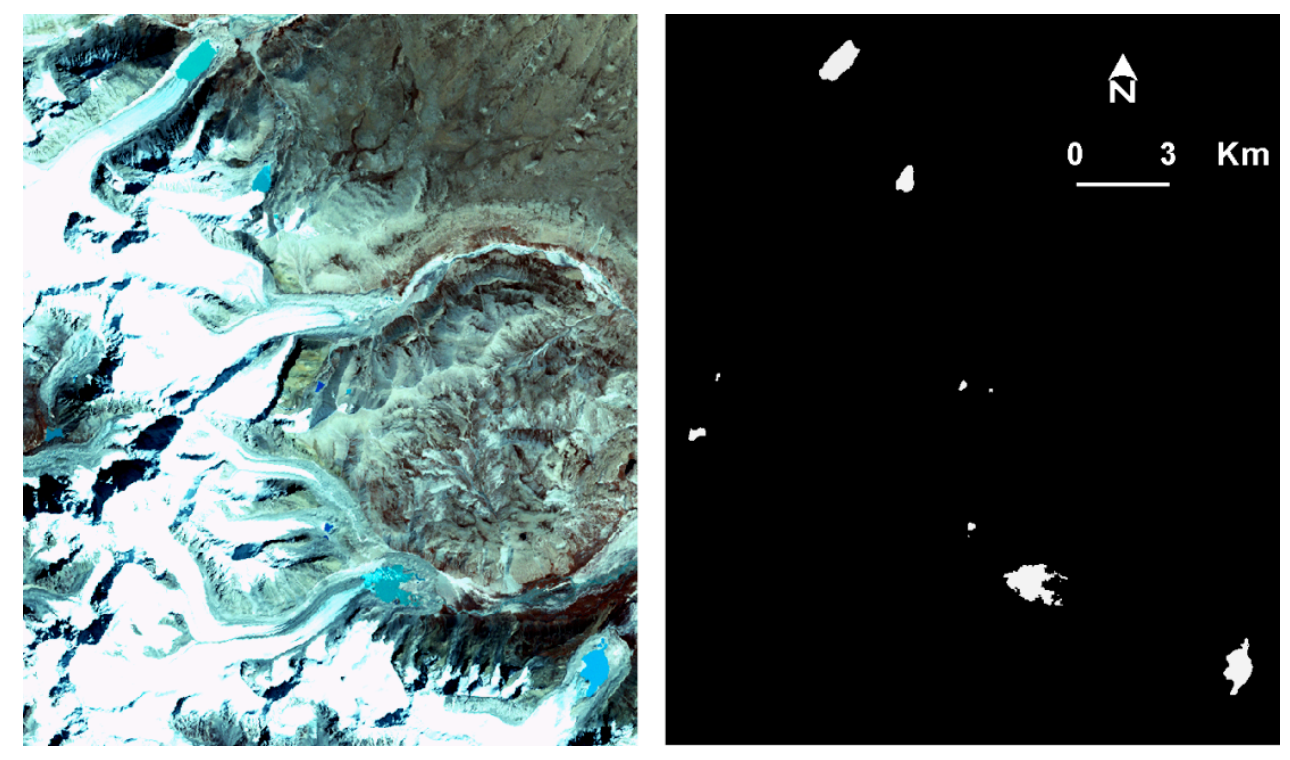

Figure 5 : LANDSAT-ETM image of the West Nepal site (left panel, October 2001) and the resulting glacial lake classification (in white, right panel).

The minimum size under which a glacial lake cannot be detected by an automatic algorithm depends on the image spatial resolution. Theoretically, a glacial lake is identified if it is composed of at least one pure pixel (i.e. a pixel whose reflectance is homogeneous and represents only one endmember). An item covering one pixel is generally not represented by one pure pixel unless it is perfectly aligned with the raster grid. On the contrary, an item covering four pixels will in the general case (i.e. not aligned with the raster grid) be represented by at least one pure pixel. Therefore, the smallest glacial lake that can be detected is 4 pixels, that is 0.36 ha (or $0.0036 \mathrm{~km}^{2}$ ) in the case of LANDSAT images. However, the thresholds $\mathrm{T}_{\mathrm{i}}$ (Figure 4) are chosen so as to be wider in order to detect mixed pixels that contain a majority of glacial lake, and the classification is therefore not restricted to pure pixels only.

Once lakes have been mapped, a label is automatically assigned to each of them, in order to identify them in a unique way among each study site. A set of geometric attributes are associated to each lake: surface, perimeter, altitude and geographic coordinates of the barycenter. Every lake is also classified as pro- or supra-glacial, using GLIMS and ICIMOD glacier inventories. A lake is classified as supra-glacial if its barycenter is included in a glacier outline, otherwise it is considered as pro-glacial. This process is of course highly dependent on the quality of this database (glacier outlines and coregistration between those outlines and the LANDSAT images). Therefore, a visual inspection was performed afterwards to detect any misclassification, by superimposing the lake inventory and glacier contours on LANDSAT images.

As shown in Table 3, for each of the seven study sites, LANDSAT images are available at the beginning of the 1990s, 2000s and in 2009. To study the temporal evolution of each lake, it is necessary to identify automatically the same lake from one image to another. Two possibilities have to be considered, depending on the type of glacial lake:

- most supra-glacial lakes are highly variable in space and time and their life-time is unpredictable (Benn et al., 2001). Therefore, it is more meaningful and relevant to consider the temporal evolution of the total area of supra-glacial lakes located on a given glacier;

- on the other hand, pro-glacial lakes are more stable over the years, allowing a comparison at the individual lake level.

Given the lack of ground truth and field measurements, it is difficult to assess the precision and quality of the classifications. It mostly depends on: (i) the quality of remotely sensed data (directly linked to the sensor quality and resolution), (ii) the precision of the data pre-processing (radiometric and geometric corrections), (iii) the quality of the classification algorithms (type of algorithm, choice of threshold values). In this study, 
the error in image co-registration does not play a key role, since comparison is not made pixel by pixel but entity by entity.

\section{Results}

4.1. Distribution of glacial lakes over the HKH

Total area and ice-covered area differ from one study site to another, therefore the comparison of absolute lake areas between sites is not meaningful. Thus, in the following, lake areas have been normalized with the overall glacierized area of each study site (thereby taking into account the fact that a highly glaciated site is more likely to bear glacial lakes). As shown by Figure $6 a$, eastern sites show the largest glacial lake areas $\left(1.7 * 10^{-2}\right.$ ha/ha for Western Nepal, $1.1 * 10^{-2}$ ha/ha Everest and $1.8^{*} 10^{-2}$ ha/ha Bhutan). In the central and western parts of the HKH, glacial lake areas are about two orders of magnitude lower, ranging from $2.2 * 10^{-4}$ to $6.7 * 10^{-4}$ ha/ha.

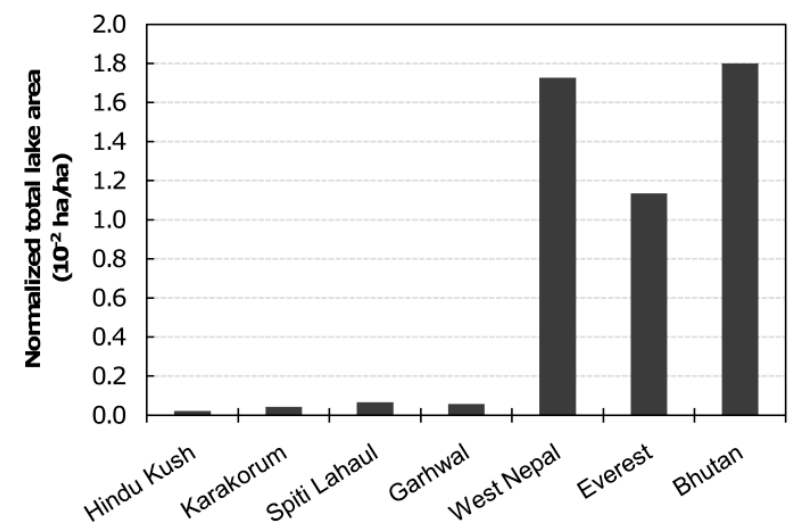

(a)

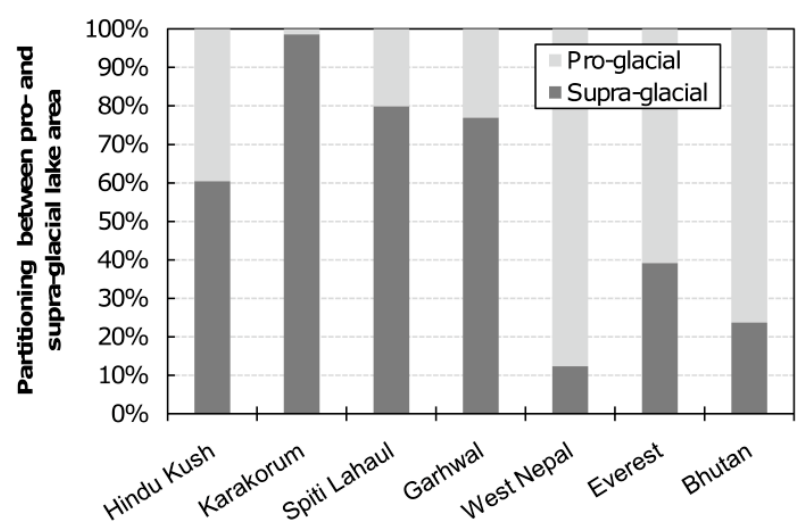

(b)

Figure 6: (a) Total glacial lakes area in 2009, normalized with the overall glacierized area of each site. (b) Partitioning between pro- and supra-glacial lakes for the seven study sites.

Partitioning, in terms of surface, between pro- and supra-glacial lakes also greatly varies among study sites. In the western part of the $\mathrm{HKH}$, there is a majority of supra-glacial lakes (Figure $6 \mathrm{~b}$ ). We link this observation with the type of glaciers found in this region: mainly long (more than $10 \mathrm{~km}$ ) debris-covered glaciers, a configuration favorable to supra-glacial lake development (Richardson and Reynolds, 2000).

Another interesting characteristic of glacial lakes is their altitude. In Nepal and Bhutan, lakes are at the same altitude as the glacier termini, since they are in majority pro-glacial and are the exutory of the glacier catchments. In other study sites, most of the lakes are supra-glacial, located on the glacier itself, thus at a higher altitude than the glacier terminus (Table 2).

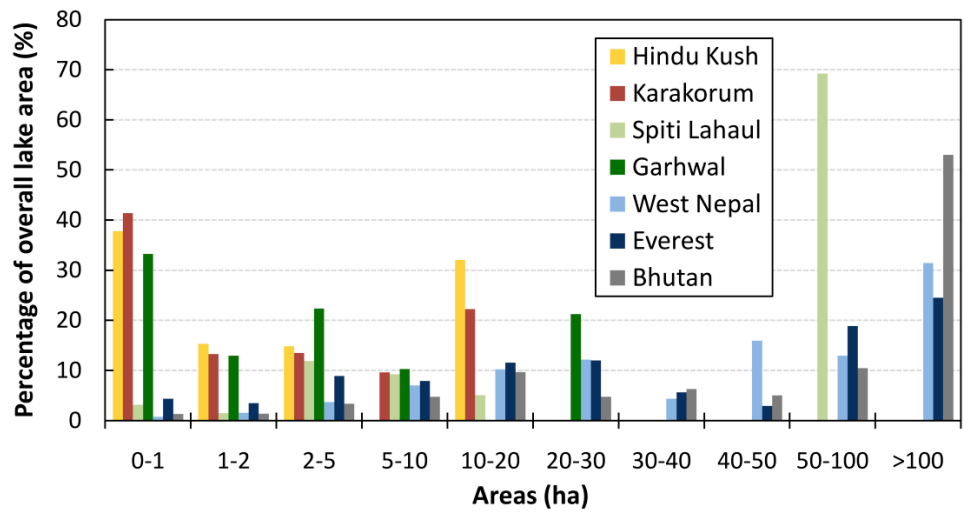

Figure 7: Percentage of overall lake area for different area classes and for the seven study sites in 2009. In this figure, each supra-glacial lake is considered as a single entity. 
Individual lake size also greatly varies from one study site to another (Figure 7). Smaller lakes (less than 20 hectares) dominate in the west (in the Hindu Kush, Karakorum, and to a lesser extent in Spiti Lahaul and Garhwal). In Spiti Lahaul, two dis-proportionally large lakes (between 50 and 100 hectares each) located in the northern part of the site represent $70 \%$ of the total lake coverage. In the east (West Nepal, Everest and Bhutan), the majority of lake coverage is represented by lakes greater than 50 hectares.

\subsection{Evolution of glacial lakes during 1990-2009}

For each study site, the total area covered by glacial lakes has been computed in 1990, 2000 and 2009, in order to evaluate changes in lake areas over two decades. Those three dates are used to label time periods in the figures and text below in the sake of simplicity, although the actual date of acquisition of LANDSAT images slightly differs from one study site to another (Table 3).

Three characteristic zones can be distinguished on Figure 8: (i) zone 1 (western sites) where lake areas have generally decreased, (ii) zone 2 (central sites) where absolute lake areas slightly increased, (iii) zone 3 (eastern sites) where lake expansion is the largest. As for the climatic gradient, Spiti Lahaul and Garhwal regions do represent a transition zone between the East and West of the HKH mountain range.

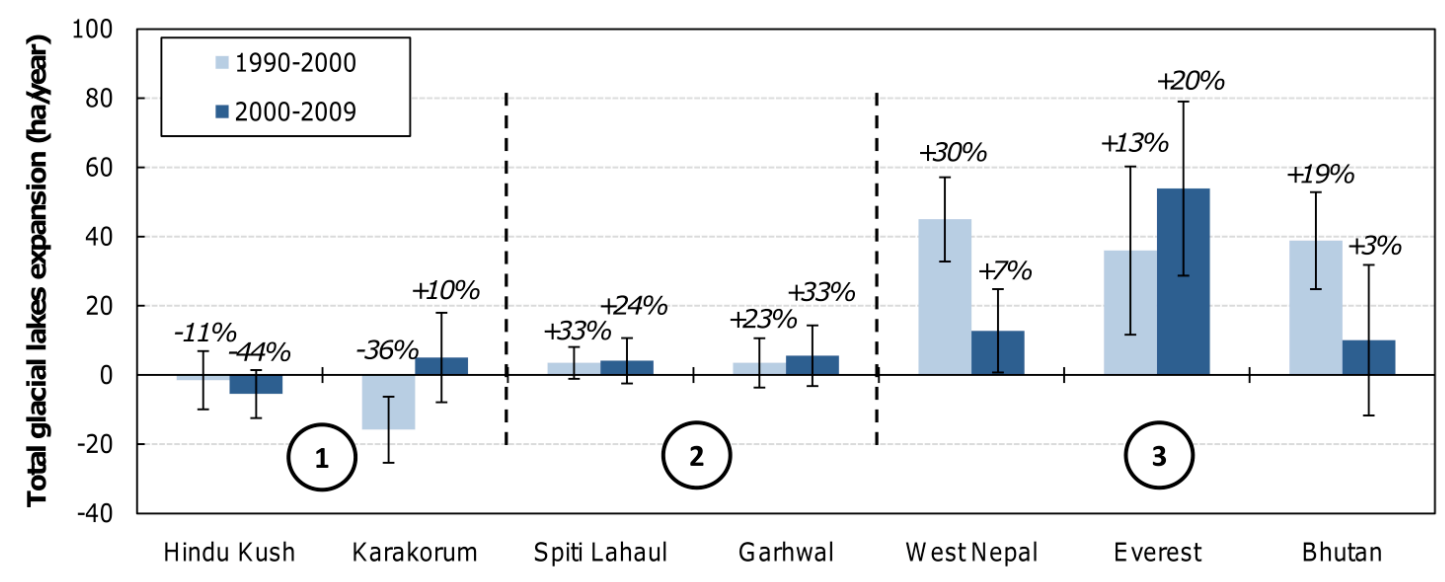

Figure 8: Change in total glacial lake area during the past two decades. Error bars correspond to the RMS error computed on the basis of an error of \pm 1 pixel on the outlines of lakes.

Comparison between 1990-2000 and 2000-2009 shows that lake area changes are not steady. Hindu Kush is the only study site where lake area has continuously decreased, whereas in Karakorum, the lake reduction in the 1990s is only partly compensated by their growth in the 2000s. For the Spiti Lahaul and Garhwal sites, glacial lake expansion remains more or less the same in the 2000s, at a rate of $5 \mathrm{ha} /$ year. In West Nepal and Bhutan, lake area growth shows a strong slow down in the 2000s, dropping to $15 \mathrm{ha} /$ year (whereas in the 1990s it reached 40 ha/year). Finally, lake expansion rates are increasing in the Everest region, as their global expansion rate grew from 36 to 53 ha/year between the 1990s and the 2000s.

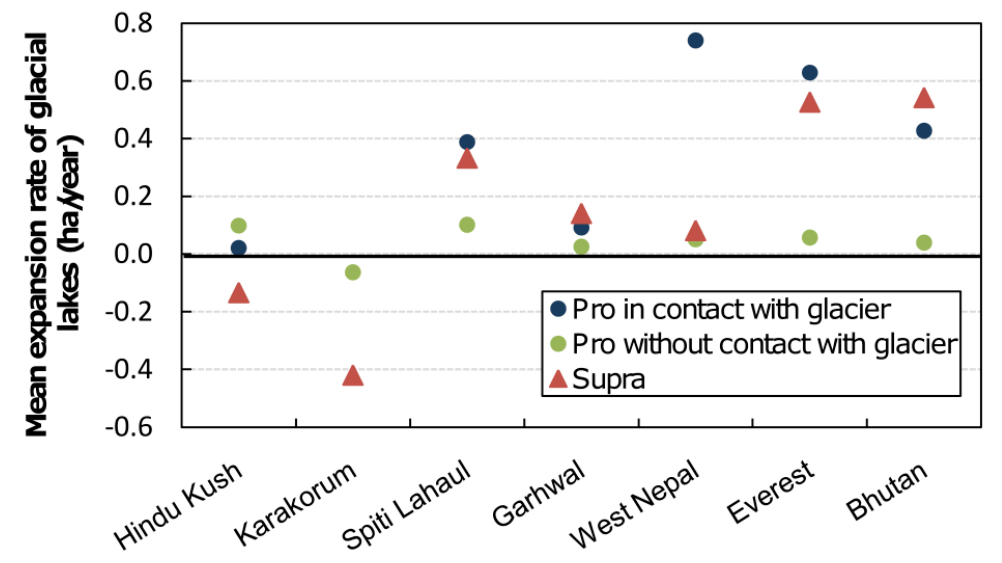

Figure 9: Mean expansion rate of glacial lakes according to their type, between 1990 and 2009. 
Expansion rates of individual lakes between 1990 and 2009 are presented in Figure 9, with a distinction between supra- and pro-glacial. Among pro-glacial lakes two categories are distinguished depending whether the lake is in contact or not with glacier ice.

The expansion rate of supra-glacial lakes is always higher than the one of pro-glacial lakes which are not in contact with the glacier termini. On the other hand, pro-glacial lakes in contact with a glacier have a similar (or even higher) expansion rate than supra-glacial lakes.

\section{Discussion}

\subsection{Glacial lake inventory by remote sensing}

The use of multitemporal satellite images for glacial lake monitoring is a well known technique. The originality of our study is that our lake inventory has been combined with a glacier inventory to differentiate pro- and supra-glacial lakes. Obviously, the classification of the lakes is highly dependant on the quality of glacier inventory. The latter is heterogeneous (Section 2.2) and build on image interpretation. The digitalization of glaciers has been made by different operators, some of them included pro-glacial lakes in the glacier contour whereas some did not. Therefore, a visual inspection was needed after the automatic classification of glacial lakes to identify misclassified lakes before the interpretation of the results. The limited number of outliers (Table 4), were mostly in eastern sites, where, after visual inspection, pro-glacial lakes are more numerous than in the original classification.

The strength of the method presented in this study is its homogeneity. The same classification algorithm and same data set has been used for each study site. Therefore, the result comparison from one region to another remains coherent.

The uncertainty of a single glacial lake area has been computed, by assuming that the lake margin is mapped with an error of \pm 1 pixel along its perimeter. This uncertainty can be considered as conservative, compared to Fujita et al. (2009) who assumed an error of \pm 0.5 pixel along the perimeter of the Imja lake, Everest region (Table 1 in Fujita et al., 2009). They reported an area of the lake of $84.4 \pm 3.6$ ha on the $14^{\text {th }}$ of October 2000, while Bolch et al. (2008a) reported an area of 76.6 ha for that same lake on the $30^{\text {th }}$ of October 2000 . Both values remain within the errors bars of the surface calculated in our study $(83.8 \pm 26.3 \mathrm{ha})$, on the $30^{\text {th }}$ of October 2000. In January 2008, the area of Imja lake was $92.0 \pm 3.6$ ha according to Fujita et al. (2009). In this study, we report an area of $113.8 \pm 32.8$ ha on the $31^{\text {rst }}$ of October 2009 (22 months after), which shows that Imja lake is still expanding.

\begin{tabular}{lr}
\hline \multicolumn{1}{c}{ Site name } & $\begin{array}{c}\text { Number of lakes misclassified / } \\
\text { Total number of lakes }\end{array}$ \\
\hline Hindu Kush & $1 / 102$ \\
Karakorum & $0 / 422$ \\
Spiti Lahaul & $0 / 35$ \\
Garhwal & $1 / 233$ \\
West Nepal & $16 / 116$ \\
Everest & $30 / 583$ \\
Bhutan & $12 / 203$ \\
\hline
\end{tabular}

Table 4: Quantification of automatic classification errors between pro- and supra-glacial lakes due to incorrect glacier outlines.

Bolch et al. (2008a) also found 19 supra-glacial lakes with a total area of $0.08 \mathrm{~km}^{2}$ on Khumbu glacier, and 19 lakes totalizing $0.03 \mathrm{~km}^{2}$ on Lhotse glacier in the Everest region on the $30^{\text {th }}$ of October 2000. Our respective values for Khumbu glacier $\left(27\right.$ lakes, $\left.0.27 \mathrm{~km}^{2}\right)$ and Lhotse glacier $\left(12\right.$ lakes, $\left.0.05 \mathrm{~km}^{2}\right)$ on the 
same image differ because the extent of the glaciers are not defined the same way (depending whether tributary glaciers are included or not in the contour of the main glacier).

Among the 50 glacial lakes investigated by Komori (2008), 12 are included in our Bhutan study site. The total difference between the area of those lakes ( 986 ha) given by Komori (2008) in November and December 2001 and the value of this present study ( 971 ha) on the $4^{\text {th }}$ November 2001 is 15 ha, which shows the good coherency of our classification algorithm with former studies.

\subsection{Pro- and supra-glacial lake variations}

Glacial lake sizes and surface variations are closely linked and governed by their expansion processes, which depend on the type of lake.

The expansion of supra-glacial lakes is driven by three main mechanisms which contribute to ice ablation (Benn et al., 2001):

(i) Subaerial melting of exposed ice cliff surrounding the lake. On debris-covered glaciers, an ice slope larger than $38^{\circ}$ cannot bear substantial debris (Röhl, 2008). Therefore, only small and thin deposit can subsist on steeper slopes, decreasing the ice albedo and enhancing its melting rate.

(ii) Water-line melting. The low albedo of the lake combined with water advection by the wind provides enough energy to melt ice at the water-line (Reynolds, 2000). This process produces thermoerosional notches that weaken the surrounding ice cliffs on the pond.

(iii) Calving of ice blocks into the lake.

Supra-glacial lakes can also have an impact on glacier dynamics. As shown by Röhl (2008), their expansion can increase the buoyancy of the glacier until its whole terminus become buoyant. This could modify the stress regime of the glacier ice and increase the terminus disintegration rate by calving.

Many authors have mentioned the high temporal variability in size, location and geometry of supra-glacial lakes (Benn et al., 2001; Röhl, 2008). The subaerial ice loss processes are of greater importance compared to subacqueous processes (Röhl, 2008). Therefore, the supra-glacial lake expansion is likely to occur in the horizontal dimension, resulting in a great area variation.

Regarding pro-glacial lakes, two options can be considered:

(i) A pro-glacial lake in contact with the glacier. In this case, expansion mechanisms upstream are the same as supra-glacial lakes (subaerial melting, water-line melting and ice calving).

(ii) A pro-glacial lake disconnected from the glacier (no contact with glacier ice). In this scenario, water inputs are reduced and can only arise from drainage of glacier melt water or precipitation.

Pro-glacial lakes, as they are constrained by surrounding moraines, show little variability in space. The mean displacement of pro-glacial lake barycenter is 70 m over 20 years (between 1990 and 2009) for the seven study sites, which is small compared to their size (most of the time, pro-glacial lakes are over $1 \mathrm{~km}-\mathrm{long}$ ) and the image resolution $(30 \mathrm{~m}$ ). Part of this displacement may be explained by mis-registration (typically 1 pixel or $30 \mathrm{~m}$ ) between the LANDSAT scenes.

As supra-glacial lakes are more variable and less stable over time, their opportunity to expand over long time-scales is limited. Therefore, their size remains smaller than the one of pro-glacial lakes. Indeed, supraglacial lakes are more numerous in the west (Figure 6b), where lakes are the smallest (Figure 7). In addition, on average over the seven study sites the size of pro-glacial lakes is higher $(9.1 \mathrm{ha})$ than supra-glacial ones (4.3 ha). Further investigations are needed to document their variability and to understand these processes and more than one image per decade is required for this purpose. This could be done by using satellite data with high temporal resolution, such as FORMOSAT-2 (Courault et al., 2008; Gardelle et al, 2010), in order to monitor supra-glacial lakes on a monthly or weekly step. For higher temporal resolution at specific sites, terrestrial photographs might be more suitable than satellite images (Röhl, 2008).

The mean expansion rate of glacial lakes (Figure 9) shows differences between pro-glacial lakes in contact or not with glacier ice. When pro-glacial lakes are located away from a glacier terminus, the only possible 
water input comes from drainage of upstream glacier melt water or precipitation. As for pro-glacial lakes in contact with a glacier, additional water inputs are the same as for supra-glacial lakes: subaerial melting, water-line melting and calving of glacier front into the lake. Therefore, pro-glacial lakes which are in contact with a glacier are more likely to grow faster than the ones located away from a glacier tongue, as water inputs are more important in the first case.

In Bhutan, Komori (2008) already investigated growth characteristics of glacial lakes and reported expansion rates for 19 lakes, ranging from 0 to $3.7 \mathrm{ha} / \mathrm{y}$ (between 1960s and 2001). In our study (between 1990 and 2009), rates are even more scattered (between 0.01 and $4.04 \mathrm{ha} / \mathrm{y}$ ), but the time period and the number of lakes considered here are different. Komori (2008) investigated 19 lakes whereas in this study the mean expansion rates in Bouthan are based on 203 lakes.

\subsection{Glacial lake and climate variations}

Lake area variations are mainly due to a change in their hydric balance. According to Xu and Feng (1994), the latter can be modified through water inputs (precipitation and glacier melting) or outputs (evaporation, infiltration via englacial conduits or discharge through a drainage channel in the case of proglacial lakes). Thus, a lot of complex parameters are involved in the water budget of glacial lakes, but many of them remain poorly known. In addition, water budgets differ from one glacial lake to another (especially inflitration and discharge), which makes their quantification very difficult.

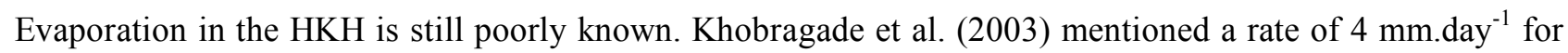
the lake Nainita at $2000 \mathrm{~m}$ in Uttaranchal, India. A rough estimation of this rate at higher altitudes in the HKH can be made with the Jensen-Haise model (Khobragade et al., 2003; Delclaux et al., 2007):

$$
E_{v}=a\left(T_{a}+b\right) \frac{R_{n s}}{\rho \lambda}
$$

where $a, b$ are coefficients, $T_{a}$ is the air temperature, $R_{n s}$ is the net solar radiation, $\rho$ the density of water and $\lambda$ the latent heat of vaporization. This leads to an evaporation rate of $1 \mathrm{~mm}^{-d a y}{ }^{-1}$ in winter and $3 \mathrm{~mm} \cdot \mathrm{day}^{-1}$ in summer, which can be considered negligible in the hydric balance of glacial lakes. Infiltration can hardly be quantified without in situ measurement, but can be considered as a constant output on a long-term hydric balance. Discharge through a drainage channel or overflow over a damming moraine are limiting factors to glacial lake expansion, as the maximum water storage depends on the height of the dam and/or the height of the drainage channel through the dam.

Water inputs into a glacial lake are closely linked with changes in precipitation and ablation process of glaciers. The impact of precipitation is twofold: (i) snow and liquid precipitations over the catchment are a direct input for the lake with different time-lags, (ii) solid precipitation is an accumulation input for glaciers and therefore an indirect water input for glacial lake (snow is stored by the glacier until it is released via ablation processes into the lake). The glacier ablation is driven by radiative and turbulent fluxes but can be approximated with temperature on a decadal time scale (Hock, 2003).

Temperature and precipitation data over the entire HKH range since the mid twentieth century are rare. Precipitation rates can be obtained from the NCEP data (National Centers for Environmental Prediction), since 1948 for reanalysis I and since 1979 for reanalysis II. However, the reliability of this data set is questionable, as it is derived solely from model fields forced by data assimilation (Kalnay et al., 1996). TRMM (Tropical Rainfall Measuring Mission, launched 27 November 1997) would have been a good alternative but do not cover the western part of our study area (Hindu Kush) and data are restricted to the most recent period. The Global Precipitation Climatology Project (GPCP) seems more suitable as it is built only on satellite and gauge observations. As for temperatures, they can be derived from the NCEP reanalysis with a better level of reliability than precipitation since they are strongly constrained by observation data.

Precipitation has been divided into solid and liquid based on a threshold $\left(+2^{\circ} \mathrm{C}\right.$, Oerlemans (1993)) on temperature data. As shown in Table 5, trends in temperature, solid and liquid precipitations are opposite between the 90s and the 00s in the east (Bhutan, Everest and West Nepal), whereas glacial lakes show a 
continous expansion among those study sites (Figure 8). This suggests that the climate influence on glacial lakes is rather complex and cannot solely account for lake variations.

\begin{tabular}{lcccccc}
\hline Site name & \multicolumn{2}{c}{$\begin{array}{c}\text { Variation in mean annual } \\
\text { temperature }\left({ }^{\circ} \mathbf{C}\right)\end{array}$} & \multicolumn{2}{c}{$\begin{array}{c}\text { Variation in mean annual solid } \\
\text { precipitation (m) }\end{array}$} & $\begin{array}{c}\text { Variation in mean annual } \\
\text { liquid precipitation (m) }\end{array}$ \\
& $1990 s-1980 s$ & $2000 s-1990 s$ & $1990 s-1980 s$ & $2000 s-1990 s$ & $1990 s-1980 s$ & $2000 s-1990 s$ \\
\hline Bhutan & -0.05 & 0.42 & +0.194 & -0.014 & -0.233 & -0.024 \\
Everest & -0.13 & 0.38 & +0.261 & -0.375 & -0.202 & +0.194 \\
West Nepal & -0.14 & 0.27 & +0.162 & -0.200 & -0.283 & -0.065 \\
Garhwal & -0.02 & 0.15 & -0.097 & -0.066 & -0.002 & -0.162 \\
Spiti Lahaul & 0.12 & 0.21 & -0.152 & +0.021 & +0.145 & -0.240 \\
Karakorum & -0.03 & 0.41 & +0.008 & +0.025 & +0.047 & -0.006 \\
Hindu Kush & -0.02 & 0.44 & +0.078 & -0.056 & +0.035 & +0.077 \\
\hline
\end{tabular}

Table 5: Variation of mean annual temperature and precipitation between each decade since 1979 (Temperatures at $600 \mathrm{hPa}$ from NCEP/DOE-Reanalysis 2, precipitation from Global Precipitation Climatology Project). Precipitation has been divided into solid and liquid according to a temperature threshold of $+2{ }^{\circ} \mathrm{C}$.

\subsection{Glacial lake and glacier mass balance variations}

Glacier mass balance may be a good parameter to explain the observed glacial lake evolution. However, long-term series of mass balance records are rare in the HKH and do not spread over the entire mountain range. Table 6 provides a list of references which addressed the issue of glacier mass/volume changes in the $\mathrm{HKH}$.

There seems to be a logical link between glacier volume changes and our satellite-derived lake evolutions. Where glaciers have lost mass, lakes have grown (Garhwal, Spiti Lahaul, Everest), and, in the Karakorum, where glaciers have lost limited mass (Matsuo and Heki, 2010) or surged (Hewitt, 2005; Hewitt, 2007) lakes have shrunk. This analysis cannot be taken any further quantitatively, because study periods of mass balance are short, not homogeneous and a single glacier may not be representative of the evolution of the study site to which it belongs. Furthermore, direct or geodetic mass balance measurements are still lacking for some large regions such as the Hindu Kush and the Karakorum.

\begin{tabular}{|c|c|c|c|c|c|c|}
\hline Site name & Location & Glaciers names & $\begin{array}{l}\text { Study } \\
\text { period }\end{array}$ & $\begin{array}{l}\text { Glacier mass or } \\
\text { volume changes }\end{array}$ & Debris & Reference \\
\hline Karakorum & $\begin{array}{l}35^{\circ} 50^{\prime} \mathrm{N} \\
76^{\circ} 10^{\prime} \mathrm{E}\end{array}$ & Multiple & $1990-2000$ & Limited ice loss & Yes & $\begin{array}{l}\text { Matsuo and Heki } \\
(2010)\end{array}$ \\
\hline Spiti Lahaul & $\begin{array}{l}32^{\circ} 12^{\prime} \mathrm{N} \\
77^{\circ} 30 \mathrm{E}\end{array}$ & Chhota Shigri & $2002-2006$ & $-1.00 \mathrm{~m} / \mathrm{y}$ w.e. & No & Wagnon et al. (2007) \\
\hline Spiti Lahaul & $\begin{array}{l}32^{\circ} 12^{\prime} \mathrm{N} \\
77^{\circ} 30 \mathrm{E}\end{array}$ & Multiple & $1999-2004$ & $\begin{array}{l}\text { Between }-0.85 \\
\text { and }-0.69 \mathrm{~m} / \mathrm{y} \text { w.e. }\end{array}$ & Mixed & Berthier et al. (2007) \\
\hline Spiti Lahaul & $\begin{array}{l}32^{\circ} 14^{\prime} \mathrm{N} \\
77^{\circ} 22^{\prime} \mathrm{E}\end{array}$ & Hamtah & 2001-2006 & $-1.2 \mathrm{~m} / \mathrm{y}$ w.e. & Yes & $\begin{array}{l}\text { WGMS (2008), Zemp } \\
\text { et al. }(2008)\end{array}$ \\
\hline Garhwal & $\begin{array}{l}31^{\circ} 14^{\prime} \mathrm{N} \\
78^{\circ} 40^{\prime} \mathrm{E}\end{array}$ & Multiple & 2001-2002 & $\begin{array}{l}-0.84 \mathrm{~m} / \mathrm{y} \\
(-0.76 \mathrm{~m} / \mathrm{y} \text { w.e. })\end{array}$ & Mixed & Kulkarni et al. (2004) \\
\hline Garhwal & $\begin{array}{l}30^{\circ} 51^{\prime} \mathrm{N} \\
78^{\circ} 49^{\prime} \mathrm{E}\end{array}$ & Dokriani & $1992-2000$ & $-0.32 \mathrm{~m} / \mathrm{y}$ w.e. & Yes & Dobhal et al. (2008) \\
\hline Everest & $\begin{array}{l}27^{\circ} 58^{\prime} \mathrm{N} \\
86^{\circ} 54^{\prime} \mathrm{E}\end{array}$ & $\begin{array}{l}\text { Multiple (only } 50 \% \\
\text { of ablation area) }\end{array}$ & $1962-2005$ & $\begin{array}{l}-0.19 \mathrm{~km}^{3} \\
(-0.30 \mathrm{~m} / \mathrm{y} \text { w.e. })\end{array}$ & Yes & Bolch et al. (2008b) \\
\hline Everest & $\begin{array}{l}27^{\circ} 42^{\prime} \mathrm{N} \\
86^{\circ} 34^{\prime} \mathrm{E}\end{array}$ & $\mathrm{AX} 010$ & 1996-1999 & -0.63 m/y w.e. & Yes & $\begin{array}{l}\text { WGMS (2008), Zemp } \\
\text { et al. (2008) }\end{array}$ \\
\hline
\end{tabular}


Table 6: Characteristics of glacier mass/volume changes in the Hindu Kush Himalaya. Original units of figures regarding volume changes are diverse, therefore the conversion into $m / y$ w.e. is indicated, when possible, between brackets (by assuming that ice only, with a density of $900 \mathrm{~kg} . \mathrm{m}^{-3}$, is gained or loss).

Sensors such as ASTER (since 2000) or SPOT5-HRS (since 2002), as well as CORONA (1962-1972) provide stereographic pairs of satellite images that can be processed to obtain high-resolution DEMs. The SRTM DEM is also available in 2000 although its resolution is coarser. Glacier volume changes can be assessed by subtracting those DEMs between two or more dates (Berthier et al., 2004). In HKH, this method has been applied by Berthier et al. (2007) and Bolch et al. (2008b), respectively in Spiti Lahaul and Everest, and gave promising results for future glacier mass balance monitoring over large scale areas.

\section{Conclusion}

Distribution and evolution of glacial lakes over the past two decades in the HKH region were established using LANDSAT satellite images. Seven study sites spread along the mountain range were selected to represent the climate variability in terms of temperature and precipitation. Lakes were classified automatically using a decision tree based on reflectance values, elevation data and a glacier database (provided by GLIMS and ICIMOD).

The eastern part of the HKH is the area comprising the highest number of lakes and also the bigger ones, with a majority being pro-glacial. On the opposite, in the western part, most lakes are supra-glacial, less numerous and smaller. This distinction between East and West remains valid for lake expansion. Between 1990 and 2009, lakes have grown in Nepal and Bhutan (25 to 45 ha/year, depending on the study site), remained almost unchanged in Western India ( 4 ha/year) and their area decreased in Pakistan and Afghanistan (between -3 to -8 ha/year). The correlation of this evolution with temperature and precipitation is not straightforward, but seems to be in good agreement with the few glacier mass balance measurements currently available.

This study gave an indirect insight of what happened to the HKH cryosphere over the last 20 years, through glacial lake evolution. Our work highlights a complex pattern of lake area change, with a strong east-west gradient across the HKH that seems to confirm the general pattern of glacier change. Regionalization of glacier mass balance over the HKH is now critically needed, to better describe the contrasted response of the $\mathrm{HKH}$ cryosphere to regional climate changes.

\section{Acknowledgments}

J.G. acknowledges a PhD fellowship from the French Space Agency (CNES) and the French National Research Center (CNRS). We thank the United State Geological Survey (USGS) for allowing free access to their LANDSAT archive. E.B. acknowledges support from the CNES (TOSCA \& ISIS project \#114). Y.A. would like to thank the Indo-French Centre for the Promotion of Advanced Research. This work was supported by Agence Nationale de la Recherche (reference ANR-09-CEP-005-01/PAPRIKA).

\section{References}

Benn, D., Wiseman, S., Hands, K. (2001). Growth and drainage of supraglacial lakes on debris-mantled Ngozumpa Glacier, Khumbu Himal, Nepal. Journal of Glaciology, 47 (159), 626-638.

Berthier, E., Arnaud, Y., Baratoux, D., Vincent, C., Rémy, F. (2004). Recent rapid thining of the "Mer de Glace" glacier derived from satellite optical images. Geophysical Research Letters, 31, L17401. 
Berthier, E., Arnaud, Y., Kumar, R., Ahmad, S., Wagnon, P., Chevallier, P. (2007). Remote sensing estimates of glacier mass balances in the Himachal Pradesh (Western Himalaya, India). Remote Sensing of Environment, 108, 327-338.

Böhner, J. (2006). General climatic controls and topoclimatic variations in Central and High Asia. Boreas, $35,279-295$.

Bolch, T., Buchroitner, M., Peters, J., Baessier, M., Bajracharya, S. (2008a). Identification of glacier motion and potentially dangerous glacial lakes in the Mt. Everest region/Nepal using spaceborne imagery. Natural Hazards and Earth System Sciences, 8, 1329-1340.

Bolch, T., Buchroithner, M., Pieczonka, T., Kunert, A. (2008b). Planimetric and volumetric glacier changes in the Khumbu Himal, Nepal, since 1962 using Corona, Landsat TM and ASTER data. Journal of Glaciology, 54 (187), 592-600.

Bookhagen, B., \& Burbank, D. (2006). Topography, reflief, and TRMM-derived rainfall variations along the Himalaya. Geophysical Research Letters, 33, L08405.

Courault, D., Bsaibes, A., Kpemlie, E., Hadria, R., Hagolle, O., Marloie, O., Hanocq J.F., Olioso, A., Bertrand, N., Desfonds, V. (2008). Assessing the Potentialities of FORMOSAT-2 Data for Water and Crop Monitoring at Small Regional Scale in South-Eastern France. Sensors, 8, 3460-3481.

Delclaux, F., Coudrain, A., Condom, T. (2007). Evaporation estimation on lake Titicaca: a synthesis review and modelling. Hydrological Processes, 21, 1664-1677.

Dobhal, D. P., J. T. Gergan, and R. J. Thayyen (2008). Mass balance studies of the Dokriani Glacier from 1992 to 2000, Garhwal Himalaya, India. Bulletin of Glaciological Research, 25, 9-17.

Dyurgerov, M., Meier, M. (2005). Glaciers and the changing Earth system: a 2004 snapshot. Occasional paper, Boulder, CO, Insitute of Arctic and Alpine Research.

Fujita, K. (2008). Effect of precipitation seasonality on climatic sensitivity of glacier mass balance. Earth and Planetary Science Letters, 276, 14-19.

Fujita, K., Suzuki, R., Nuimura, T., Sakai, A. (2008). Performance of ASTER and SRTM DEMs, and their potential for assessing glacial lakes in the Lunana region, Bhutan Himalaya. Journal of Glaciology, 54 (185), $220-228$.

Fujita, K., Sakai, A., Nuimura, T., Yamaguchi, S., Sharma, R. (2009). Recent changes in Imja Glacial Lake and its damming moraine in the Nepal Himalaya revealed by in situ surveys and multi-temporal ASTER imagery. Environmental Research Letters, 4.

Gardelle, J., Hiernaux, P., Kergoat, L., Grippa, M. (2010). Less rain, more water in ponds: a remote sensing study of the dynamics of surface waters from 1950 to present in pastoral Sahel (Gourma region, Mali). Hydrology and Earth System Sciences, 14, 309-324.

Hewitt, K. (2005). The Karakoram anomaly? Glacier expansion and the "elevation effect", Karakoram Himalaya. Mountain Research and Development, 25 (4), 332-340.

Hewitt, K. (2007). Tributary glaciers surges: an exceptional concentration at Panmah Glacier, Karakoram Himalaya. Journal of Glaciology, 53 (181), 181-188.

Hock, R. (2003). Temperature index melt modelling in mountain areas. Journal of Hydrology, 282, 104-115.

Huffman, G., Bolvin, D. (2009). GPCP Version 2.1 combined precipitation data set documentation. Laboratory for Atmosphere, NASA Goddard Space Flight Center and Science Systems and Applications.

Huggel, C., Kääb, A., Haeberli, W., Teysseire, P., Paul, F. (2002). Remote sensing based assessment of hazards from glacier lake outburst: a case study in the Swiss Alps. Canadian Geotechnical Journal, 39, 316330. 
ICIMOD. (2007). Inventory of Glaciers, Glacial Lakes and Identification of Potential Glacial Lake Outburst Flood (GLOFs) Affected by Global Warming in the Mountains of the Himalayan Region. International Centre for Integrated Mountain Development, Kathmandu. DVD-ROM.

Kääb, A., Wessels, R., Haeberli, W., Huggel, C., Kargel, J., Khalsa, S. (2003). Rapid ASTER Imaging Facilitates Timely Assessment of Glacier Hazards and Disasters. EOS Transactions American Geophysical Union, 84 (13), 117-124.

Kääb, A., Huggel, C., Fischer, L., Guex, S., Paul, F., Roer, I., Salzmann, N., Schlaefli, S., Schmutz, K., Schneider, D., Strozzi, T., Weidmann, Y. (2005). Remote sensing of glacier- and permafrost-related hazards in high mountains: an overview. Natural Hazards and Earth System Sciences, 5, 527-554.

Kalnay, E., Kanamitsu, M., Kistler, R., Collins, W., Deaven, D., Gandin, L., Iredell, M., Saha, S., White, G., Woollen, J., Zhu, Y., Leetmaa, A., Reynolds, R., Chelliah, M., Ebisuzaski, W., Higgings, W., Janowiak, J., Mo, K.C., Ropelewski, C., Wang, J., Jenne, R., Joseph, D. (1996). The NCEP/NCAR 40-years reanalysis project. Bulletin of the American Meteorological Society, 77, 437-470.

Kanamitsu, M., Ebisuzaki, W., Woollen, J., Yang, S.-K., Hnilo, J., Fiorino, M., Potter, G.L. (2002). NCEPDOE AMIP-II Reanalysis (R-2). Bulletin of American Meteorological Society, 1631-1643.

Kargel, J., Abrams, M., Bishop, M., Bush, A., Hamilton, G., Jiskoot, H., Kääb, A., Kieffer, H.H., Lee, E.M., Paul, F., Rau, F., Raup, B., Shroder, J.F., Soltesz, D., Stainforth, D., Stearns, L., Wessels, R. (2005). Multispectral imaging contributions to global land ice measurements from space. Remote Sensing of Environment, 99, 187-219.

Khobragade, S., Ojha, C., Bhatia, K. (2003). Estimating evaporation rates from lake Nainital (Uttaranchal), India: comparison of various models. V. Singh, \& R. Yadava (Publ.).

Komori, J. (2008). Recent expansions of glacial lakes in the Bhutan Himalayas. Quaternary International, 184, 177-186.

Kulkarni, A., Rathore, B., Alex, S. (2004). Monitoring of glacial mass balance in the Baspa basin using accumulation and area ratio method. Current Science, 86 (1), 185-190.

Matsuo, K., Heki, K. (2010). Time-variable ice loss in Asian high mountains from satellite gravimetry. Earth and Planetary Science Letters, 290, 30-36.

Oerlemans, J. (1993). A Model for Surface Balance of Ice Masses. Part 1: Alpine Glaciers. Z. Gletscherk. Glazialgeol., 27-28, 1991-1992, 63-83.

Quincey, D., Richardson, S., Luckman, A., Lucas, R., Reynolds, J., Hambrey, M., Glasser, N.F. (2007). Early recognition of glacial lake hazards in the Himalaya using remote sensing datasets. Global and Planetary Change, 56, 137-152.

Raup, B., Racoviteanu, A., Khalsa, S., Helm, C., Armstrong, R., Arnaud, Y. (2007). The GLIMS geospatial glacier database: a new tool for studying glacier change. Global and Planetary Change, 56, 101-110.

Reynolds, J. (2000). On the formation of supraglacial lakes on debris-covered glaciers. In M. Nawako, C. Raymond, \& A. Fountain (Eds.), Debris-covered Glaciers. IAHS Publication, 264, 153-161.

Richardson, S., Reynolds, J. (2000). An overview of glacial hazards in the Himalayas. Quaternary International, 65/66, 31-47.

Röhl, K. (2008). Characteristics and evolution of supraglacial ponds on debris-covered Tasman Glacier, New Zealand. Journal of Glaciology, 54 (188), 867-880.

Sakai, A., Chikita, K., Yamada, T. (2000). Expansion of a moraine-damned glacial lake, Tsho Rolpa, in Rolwaling Himal, Nepal Himalaya. Limnology and Oceanography, 45 (6), 1401-1408.

Wagnon, P., Linda, A., Arnaud, Y., Kumar, R., Sharma, P., Vincent, C., Pottakkal, J.G., Berthier, E., Ramanathan, A., Hasnain, S.I., Chevallier, P. (2007). Four years of mass balance on Chhota Shigri Glacier, 
Himachal Pradesh, India, a new benchmark glacier in the western Himalaya. Journal of Glaciology, 53 (183), 603-611.

Wessels, R., Kargel, J., Kieffer, H. (2002). ASTER measurements of supraglacial lakes in the Mount Everest region of the Himalaya. Annals of Glaciology, 34, 399-407.

WGMS. (2008). Fluctuations of Glaciers 2000-2005, Volume IX. ICSU (FAGS)/IUGG (IACS)/UNEP/UNESCO/WMO, World Glacier Monitoring Service, Zurich, Switzerland.

$\mathrm{Xu}$, D., Feng, Q. (1994). Dangerous glacier lakes and their outburst features in the Tibetan Himalayas. Bulletin of Glacier Research, 12, 1-8.

Yamada, T., Sharma, C. (1993). Glacier Lakes and Outburst Floods in the Nepal Himalaya. Proceedings of the Kathmandu Symposium. IAHS Publication, 218, 319-330.

Zemp, M., Hoezle, M., Haeberli, W. (2009). Six decades of glacier mass-balance observations: a review of the worldwide monitoring network. Annals of Glaciology, 50, 101-111. 